\title{
Review of New Formats for Fracture Mechanics Parameters
}

\author{
J. D. Landes ${ }^{a}$ and J. R. Donoso ${ }^{b}$ \\ ${ }^{a}$ University of Tennessee, Knoxville, USA \\ ${ }^{\text {b }}$ Universidad Tecnica Federico Santa Maria, Valparaiso, Chile
}

удК 539.4

\section{Обзор новых форматов параметров механики разрушения}

\author{
Дж. Д. Ландес ${ }^{\mathrm{a}}$, Х. Р. Доносо ${ }^{0}$ \\ a Университет Теннесси, Ноксвилл, США \\ ${ }^{\sigma}$ Технический университет им. Федерико Санта Марии, Вальпараисо, Чили
}

Предложень новые методы для описания параметров механики разруиения. Методы предполагают использование “общего формата" определения взаилосвязи между закономерностями деформации тела или образиа с трециной и процессом деформирования при испьтыниях на растяжение, а также "краткого формата", в котором обычные поли номиальные зависимости для описания основных параметров механики разруиения могут быть суиественно упроцень, что, в свою очередь, упростит использование параметров механики разрушения в аналитических методах расчета

Ключевые слова: параметры механики разрушения, тело с трещиной, разделение нагрузки, “общий формат", “краткий формат”.

Introduction. Traditional fracture mechanics parameters used to conduct fracture toughness evaluations include, for linear-elastic behavior, both the Irwin stress-intensity factor, $K$ [1] and the Griffith energy release parameter, $G$ [2]. For nonlinear behavior the $J$-integral and crack-tip opening displacement parameters are used. These parameters are determined from both a crack-tip stress analysis and bulk material properties. Originally $K$-solutions were developed analytically, but the applicability of these analytical solutions was limited. Numerical techniques, like the finite element approach, were able to solve a much wider range of problems, and $K$-solutions could be obtained for many different geometries and loading modes. The usual finite element solutions gave results for the parameters as tabulated values, not a very convenient format to use. To make the result more usable, the tabulated values were fitted with a polynomial, written as a function of crack length, $a$, to a structural or specimen dimension, $W$. The polynomials usually contained about four to six polynomial terms in $a / W$. Examples of these polynomial fits are in the ASTM fracture toughness standards [3]. The polynomial fits could easily be used in computational programs but were more difficult to use in analytical calculations. Also, these fits did not allow the user to understand relationships between various parameters. 
An analysis of the elastic-plastic behavior of cracked bodies by Sharobeam and Landes [4], led to the development of some simple relationships that allowed parameters to be put in a different and more convenient format. Their formulation of the parameters was written as a function of the uncracked ligament, $b$, where $b=W-a$, rather than crack length. The parameters that were evaluated in this format could be determined as functions of $b / W$ and could be expressed as relatively simple functions rather than as polynomial functions. Donoso and Landes extended this analysis to linear elastic behavior and showed that for many geometries and crack lengths, the same relationships could be used to calculate parameters like $K$ and elastic compliance [5]. The format for the elastic parameters could also be expressed as a simple function of $b / W$ rather than as a polynomial function of $a / W$. The new format offered an easier way to determine and relate various parameters like $K, J$, and elastic compliance.

Load Separation. The principle of load separation was first suggested by Rice, et al. [6] in a paper that developed formulations to determine $J$ from area under a loading curve implied the need for separated load and geometry factors. Ernst and Paris [7] more formally showed that and expressed the formula in the format

$$
P=F(a / W, v / W)=G(a / W) H(v / W),
$$

where $P$ is load, the other dimensions are given in Fig. 1. They also showed that this form is necessary for the $J$ expression to be written in the classical format:

$$
J=\eta(\text { Area }) / B b .
$$

Finally Sharobeam showed from experimental results that the load could be written in a separated format like Eq. (1) for all common cracked geometries, including test specimens, tension panels with edge and central cracks and even pipe sections with circumferential through cracks. In addition he showed that the geometry function had a generic form that could be written as a power law by

$$
G(b / W)=B W(b / W)^{m},
$$

where the $m$ is the same as the $\eta$ coefficient from Eq. (2). The $H$ function in the work of Sharobeam was written only for plastic deformation. It remained to be shown that separation would work for other deformation types.

This load separation principal gave rise to several useful approaches that were used for fracture mechanics testing and analysis. Among them are the method of normalization which is used in a $J-R$ curve test like the one in ASTM E 1820 [8], the common format [5] and the concise format [8] of Donoso and Landes. This paper discusses some of the new formats and the advantages that they present in analytical calculations with fracture mechanics parameters.

Common Format. The $H$ function in Eq. (1) can be written is several forms. However, the $H$ or hardening function contains the deformation characteristics of the material. It can be derived from the tensile test deformation. One form that is useful is a power hardening form given as 


$$
H=\sigma^{*} v_{N}^{1 / n}
$$

where

$$
\sigma^{*}=\sigma_{0} /\left(\alpha \varepsilon_{0}\right)^{1 / n}
$$

Another form for the $H$ function is the three constant form that is used for the normalization procedure [8]

$$
H\left(\frac{v_{p l}}{W}\right)=\frac{L+M\left(\frac{v_{p l}}{W}\right)}{N+\left(\frac{v_{p l}}{W}\right)}\left(\frac{v_{p l}}{W}\right),
$$

where $L, M$, and $N$ are constants. Here $H$ is written only for plastic deformation.



Fig. 1. Illustration of length parameters used in equations.

The common format related the separated load to $b$ the uncracked ligament and $v_{p l}$ the plastic displacement. However, if the load is really separated, then the $H$ function should not depend on the $G$ function at all and could represent any type of deformation, not only plastic deformation. This could be creep or elastic deformation. This has already been demonstrated for creep deformation [10]. The idea of using it for elastic deformation gave rise to the concise format.

Concise Format. If the separated form of load could be written for an elastic $H$ function then it would have the form

$$
P=\mathrm{const} \cdot B W(b / W)^{\mu} E\left(v_{e l} / W\right),
$$

or

$$
B E v_{e l} / P=\text { const } \cdot(b / W)^{-\mu},
$$

but $B E v_{e l} / P$ is represented by a polynomial format of the form 


$$
\begin{gathered}
C_{L L}=\frac{1}{B E}\left(\frac{W+a}{W-a}\right)^{2}\left[2.163+12.219\left(\frac{a}{W}\right)-20.065\left(\frac{a}{W}\right)^{2}-9.9925\left(\frac{a}{W}\right)^{3}+\right. \\
\left.+20.609\left(\frac{a}{W}\right)^{4}-9.9314\left(\frac{a}{W}\right)^{5}\right],
\end{gathered}
$$

where $C_{L L}$ represents the load-line compliance for a compact specimen geometry.

If the two forms are identical, a plot of $\log \{$ polynomial $\}$ versus $\log \{b / W\}$ should give a straight line fit with a slope of $-\mu$. Some examples of this are shown in Figs. 2, 3, and 4 for the compact specimen, C(T), the single edge bend, $\mathrm{SE}(\mathrm{B})$, and the center cracked $\mathrm{M}(\mathrm{T})$ respectively. These all give the straight line fit for some of the range of $b / W$, but not the entire range. Examples of where this range works is given in Table 1 . This could depend on the deformation pattern of the particular geometry. However, the range where it is okay is usually for the most useful range of crack lengths. In addition the exponent for the elastic deformation, $\mu$ is nearly identical to the one for plastic deformation, $\eta$, suggesting that the $G$ function is not coupled to the $H$ function, Table 1 .
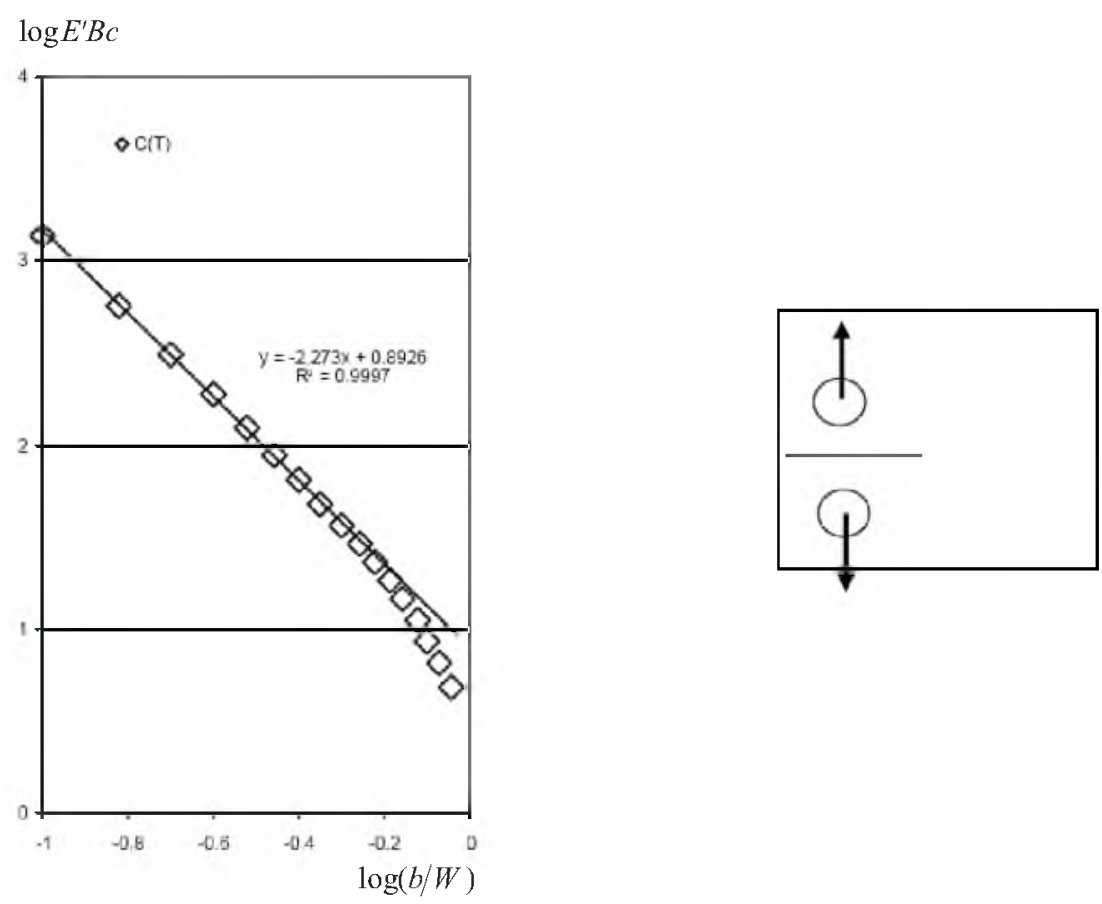

Fig. 2. Plot of $\log \{$ compliance $\}$ polynomial vs $\log [b / W], \mathrm{C}(\mathrm{T})$ specimen

A further useful application of this is in the development of $K$ form compliance using the Griffith formulation

$$
G=\frac{P^{2}}{2 B}\left(\frac{d C}{d a}\right)=\frac{K^{2}}{E^{\prime}}
$$


Review of New Formats for Fracture Mechanics Parameters

$\mathrm{T}$ a b l e 1

Comparisons of Concise Forms

\begin{tabular}{|c|c|c|c|}
\hline Geometry & Range of $a / W$ & Elastic, $\mu$ & Plastic, $\eta$ \\
\hline $\mathrm{C}(\mathrm{T})$ & $0.45-0.90$ & 2.28 & 2.24 \\
\hline $\mathrm{SE}(\mathrm{B})$ & $0.20-0.90$ & 2.05 & 2.00 \\
\hline $\mathrm{M}(\mathrm{T})$ & $0.50-0.85$ & 1.07 & 1.00 \\
\hline
\end{tabular}

$\log E^{\prime} B C$
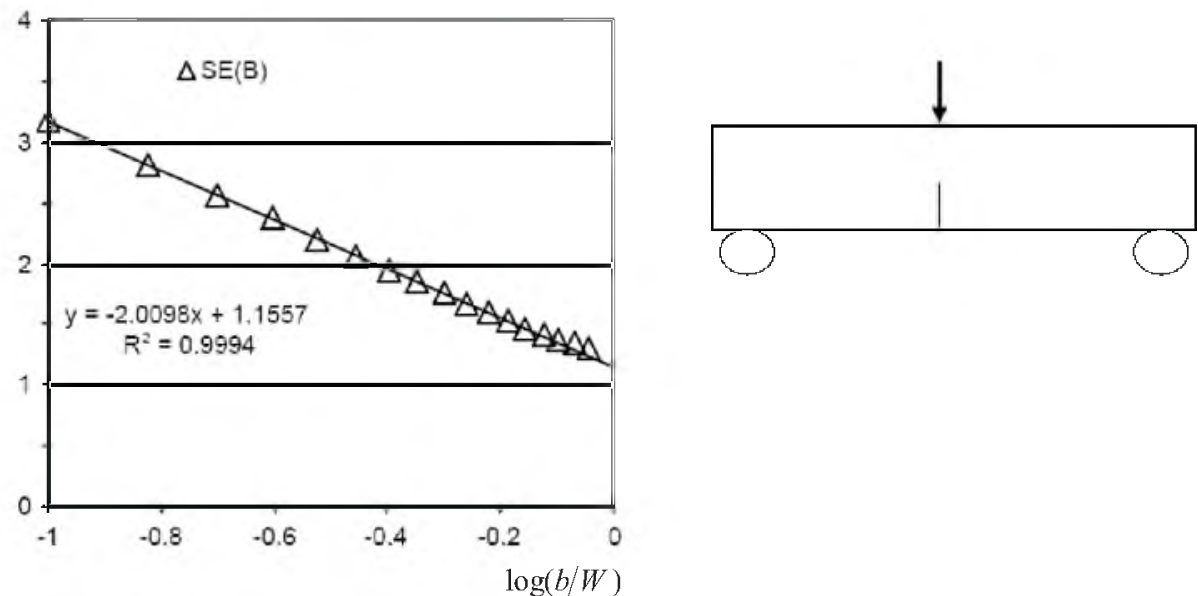

Fig. 3. Plot of $\log \{$ compliance $\}$ polynomial vs $\log [b / W]$, SE(B) geometry.


Fig. 4. Plot of $\log \{$ compliance $\}$ polynomial vs $\log [b / W], \mathrm{M}(\mathrm{T})$ geometry.

Using this the stress intensity factor $K$ can be represented by

$$
K=\frac{P}{B \sqrt{W}} \sqrt{\frac{\mu}{2 C^{*}}(b / W)^{-\mu-1}}
$$


Equations (10) and (11) are concise representations on the compliance and $K$ for common geometries. The comparison for this is the usual polynomial form of $K$ that is in the test standards, in this case the one for the compact specimen is given as

$$
\begin{gathered}
K=\frac{P}{B \sqrt{W}}\left(2+\frac{a}{W}\right)\left(1-\frac{a}{W}\right)^{-3 / 2}\left[0.886+4.64\left(\frac{a}{W}\right)^{2}-\right. \\
\left.-13.32\left(\frac{a}{W}\right)+14.72\left(\frac{a}{W}\right)^{3}-5.6\left(\frac{a}{W}\right)^{4}\right] .
\end{gathered}
$$

The standard forms in Eqs. (9) and (12) are usable in computational and numerical programs but are difficult to use analytically. Such things as solving a $d a / d N$ vs $\Delta K$, problem to predict component life or taking the derivative $d\left(K^{2}\right) / d a$ can be very complicated in the for the standard form of $K$. However, in the concise format these operations are not very difficult. Other advantages to this new concise format have been discussed by Donoso and Landes [11].

Conclusions. The separated form of load for a cracked gives rise to both a common format for load, deformation, and crack length in a cracked body. This also can be used to formulate the common fracture mechanics parameters in a much more useable format for doing analytical work using fracture parameters.

\section{Рез юм е}

Запропоновано нові методи для опису параметрів механіки руйнування. Методи припускають використання “загального формату” визначення взаємозв'язку між закономірностями деформації тіла або зразка з тріщиною $\mathrm{i}$ процесом деформування при випробуваннях на розтяг, а також “скороченого формату", де звичайні поліноміальні залежності для опису основних параметрів механіки руйнування можуть бути суттєво спрощені, що, в свою чергу, спростить використання параметрів механіки руйнування в аналітичних методах розрахунку.

1. G. R. Irwin, "Analysis of stresses and strains near the end of a crack traversing a plate," J. Appl. Mech., 6, 361-364 (1957).

2. A. A. Griffith, "The phenomena of rupture and flow in solids," Phil. Trans., 221, 163-198 (1920).

3. ASTM E 1820, Standard Test Method for Measurement of Fracture Toughness, ASTM, Annual Book of Standards, Vol. 03.01.

4. M. H. Sharobeam and J. D. Landes, "The separation criterion and methodology in ductile fracture mechanics," Int. J. Fracture, 47, 81-104 (1991).

5. J. R. Donoso and J. D. Landes, "A unifying principle for evaluating fracture toughness in the elastic and plastic regimes with two-dimensional fracture specimens," in: P. C. Paris and K. L. Jerina (Eds.), ASTM STP 1360, ASTM, West Conshohocken, Fatigue Fract. Mech., 30, 34-50 (2000). 
6. J. R. Rice, P. C. Paris, and J. M. Merkle, "Some further results of $J$-integral analysis and estimates," in: ASTM STP 536, Progress in Flaw Growth and Fracture Toughness Testing, ASTM, West Conshohocken (1973), pp. 231245.

7. H. A. Ernst, P. C. Paris, and J. D. Landes, "Estimations on $J$-integral and tearing modulus $T$ from a single specimen test record," in: R. Roberts (Ed.), ASTM STP 743, Fracture Mechanics (Thirteenth Conference), ASTM, West Conshohocken (1981), pp. 476-502.

8. J. D. Landes, Z. Zhou, K. Lee, and R. Herrera, "Normalization method for developing $J-R$ curves with the $L M N$ function," J. Test. Eval., 19, No. 4, 305-311 (1991).

9. J. R. Donoso and J. D. Landes, "Common format for developing calibration curves in elastic-plastic fracture mechanics," Eng. Fract. Mech., 47, No. 5, 619-628 (1994).

10. J. D. Landes, K.-H. Schwalbe, and J. R. Donoso, "Evaluation of the common format for creep deformation," Int. J. Press. Vess. Piping, 80, No. 7-8, 553563 (2003).

11. J. R. Donoso and J. D. Landes, "Advantages of the concise $K$ and compliance formats in fracture mechanics calculations," in: R. Chona (Ed.), ASTM STP 1406, Fatigue and Fracture Mechanics, ASTM, West Conshohocken (2001), 32, pp. 261-278. 